\title{
Enduring extremity: on Isabelle Huppert's intertextual body
}

Jules O’Dwyer

Despite proving resistant to typecasting, Isabelle Huppert has been closely bound to French cinema's sustained exploration of sexuality since even her earliest on-screen appearances. Her first performances trafficked in fantasies of virginal purity, consigning her largely to the role of erotic curiosity. We might recall, for instance, her appearance in Bertrand Blier's Les Valseuses/Going Places (1974) as the 16 year old Jacqueline, a carefree adolescent who becomes entangled in the film's coarse culture of libertinage, or her subsequent role as the suggestively named Brigitte, the reclining nude whose sunbathing we intrude upon in the similarly bucolic setting of Yves Boisset's Dupont Lajoie/The Common Man (1975). Following her cinematic breakthrough, which is typically understood to have occurred in the late 1970 s with the successive releases of La Dentellière/The Lacemaker (Goretta 1977) and Violette Nozière (Chabrol, 1978), her protagonists have only grown in complexity and psychosexual depth. If, from our contemporary vantage point, we might situate Huppert among French cinema's most enduring objects of desire, then many of her roles in post-millennial cinema demand us to clarify exactly what it is that we mean by endurance, addressing not only questions of time, periodization and historicity (durée) but also the more implicit notions of bodily performance, strain, and vulnerability that are also suggested by the term.

The sheer breadth of Huppert's filmography means that to trace a given theme across her oeuvre is, by extension, to follow the grain of French cinema over the last forty years. However, while this body of film yields a rich and compelling repository, a number of factors confound typical markers of time or indices of historicity — not least her oft-remarked 'agelessness' and the affective ties that her characters entertain with younger men ( $L$ 'école de la chair/The School 
of Flesh (Jacquot, 1998), La Pianiste/The Piano Teacher (Haneke, 2001) and Ma mère/My Mother (Honoré, 2004)). When considering Huppert's stardom as the aggregate of past roles and performances a paradox becomes apparent: the very elements that assure a coherence and stability to her star persona seem characterized by a fundamental instability. Moreover, critics have often described her overarching on-screen presence according to a negative logic, a selfeffacing persona figured as ‘blankness’ (Álvarez López and Martin 2017; LaSalle 2012, 80).

In this chapter, I consider Huppert's association with a recent tendency in art cinema to put bodies and psyches under duress. While the themes and characteristics with which she has widely become associated — sexuality, transgression, anti-psychology — resonate with a key trend in recent French filmmaking, she nonetheless occupies an uneasy relation to the cinematic zeitgeist known in French as the cinéma du corps or 'European extremity' more generally. I want therefore to explore the various ways in which the bodily, psychic, and star presence of Huppert both trouble and extend existing debates on cinematic extremity, as well as the concomitant theoretical framework through which this trend has been read. The example of Isabelle Huppert offers us a rare opportunity to bring into dialogue two distinct areas of film studies that seem on the surface to have little to say to one another: accounts of cinematic affect and extremity on the one hand, and the field of 'star studies' on the other. Considering these discourses in tandem, I explore how the imperilled star's body accrues an intertextual weight across an ever-growing body of film.

It is perhaps first worth noting the frequency with which critics have circled around these questions in previous accounts of the star. In a 2016 interview for Film Comment, Violet Lucca posed Huppert a series of questions about the physical and emotional burden of her past film performances. More specifically, she was interested in ascertaining whether the actor had ever experienced problems maintaining the distance between her many performances or if she ever 
sensed what film scholar Troy Bordun $(2017,194-5)$ has termed an 'affective bleed' between discrete roles:

Lucca: When you are taking on a new part, are you reminded of all the women you played? ... Do they keep inhabiting you? Do they become engrained in your being as soon as you have brought them to life? Or do you kind of have to leave them behind to move on and start afresh?

Huppert: Well, it's not that I have to leave them behind it's more that they are behind, you know? I think it's a perception of the spectator what you describe. It's not like you are piling roles in yourself, like there were layers of sensations from having, giving life to all of these characters. It's not more than the sea on the beach going back to where it was. It's completely volatil, it doesn't remain. (Film Comment 2016, author's transcription).

This question, while preceded by a discussion of Huppert's longstanding collaboration with Claude Chabrol, might just as well be informed by her predisposition towards the extreme edge of contemporary art cinema. Huppert's response, however, declines the premise of the question by situating this impression firmly on the side of the spectator. If this exchange seems on the surface to have misfired, its constituent parts are nonetheless engaged in a curious symbiosis. Appearing so convinced by Huppert's performances, Lucca misplaces the affective force that she describes in the actor herself, blurring the line between reality and diegesis, suggesting a slippage 'from reel to real' (Gledhill 1991, 27). Yet though the literalism of Huppert's response purports, in turn, to demystify her acting process, it actually works to cultivate the myth of her singular aura. Playing into dominant accounts of Huppert's alluring opacity, interiority here is 
once again withheld from view. Not only is it the case that the 'sea returns to its prior place' but the proverbial shoreline is shorn of its flotsam and jetsam, its intertextual baggage. As Murielle Joudet goes on to note in the only monograph dedicated to Huppert, 'characters are little more than a light veil thrown on to her, which flies away at the first gust of wind' $(2018,205) .{ }^{1}$

The exchange in this interview raises pressing questions about the intertextual dimensions of Huppert's acting. Cristina Álvarez López and Adrian Martin note that '[m]ore than with most actors, the border between actor and role seems to evaporate swiftly ... It is almost impossible to distinguish Huppert's “characterization” from one performance to the next' $(2017,23)$. Lucca's question also bespeaks a broader strain of commentary surrounding how the recursiveness of Huppert's casting choices relates to ethical and representational considerations. For example, if we survey the critical reaction of Paul Verhoeven's Elle (2016) it is instructive to note that Catherine Wheatley's critique of the film's sexual politics hinges on the director's casting choices. Part of the problem, Wheatley suggests, is that the role cannot be fully dissociated from that of Erika Kohut in La Pianiste/The Piano Teacher, a film that also gained notoriety due to the stark depiction of sexual violence (Sight and Sound 2017). In a move that typifies dominant discourses surrounding Huppert, the evocation of earlier films is seen to lend a further extratextual dimension to her later work, inflecting our understanding of Elle's sexual politics - a film in which the boundaries between the real and the fantasmatic are far from assured, even within the closed economy of its narrative. Joudet similarly privileges her portrayal of Erika in Haneke's film in her retrospective of her career, writing that 'from La Pianiste onwards, Isabelle Huppert will ritualize the suffering that she undergoes' $(2018,146)$. But what is most striking in Joudet's account is not that this performance represents a powerful iteration of the sexual dynamics that contour Huppert's more recent work, but that it comes to stand in for the function of acting tout court: 
A paroxysmal, convulsive illustration of what an actor is, [La Pianiste] also represents, in its most pared-back form, a synthesis of all the characters that Huppert has so far embodied. The film juggles with the themes that punctuate her filmography: to be bored to do harm - to harm oneself $(2018,146$; emphasis added $)$

Of note here is how Joudet edges incrementally from the particular to the general: from $L a$ Pianiste, to Huppert's filmography, and then to performance more generally. In this chapter, I am indeed interested in using Huppert's performances as a case study for 'what an actor is' and to account for the ways in which these performances problematize questions of actor labour in 'extreme' cinema. ${ }^{1}$ In what follows, then, I consider the discursive parameters of recent extreme arts cinema and discuss the adjacent relation that Huppert occupies in relation to it. I subsequently take as my focus three films, Haneke's La Pianiste, Catherine Breillat's Abus de faiblesse (2013) and Paul Verhoeven's Elle (2016), which, while tarrying with questions of sex and violence, nonetheless resist easy absorption into the overarching narrative of the cinéma du corps. This common assessment, I wager, is due in part to the constitutive role played by Huppert.

\section{Extremity, stardom, methodological antagonism}

The rise in graphic depictions of violence and the vicissitudes of sexuality in French cinema since the early 2000s has been named and discussed under a number of often-interchangeable designations, including the 'New French Extremity' (Quandt 2011 [2004]), 'new extremism' (Horeck and Kendall 2011, 5) and 'cinema of sensation' (Beugnet 2007, 14). In keeping with the corporeal focus of this chapter, I adopt the label cinéma du corps to name a filmmaking mode 
whose agenda is, to draw on Tim Palmer's oft-cited formulation, 'an on-screen interrogation of physicality in brutally intimate terms' $(2011,57)$. While debates surrounding which films and directors fall squarely within the designation of hair-raising cinema has often amounted to hair splitting (discussions which quite tellingly reveal the subjective dimension of cinematic 'transgression') the primary fault line in scholarship has been whether to organize this corpus according to profilmic content - (Quandt $(2011,18)$ furnishes us with the obligatory keywords: "flesh and blood, sex and violence") — or whether to admit into this fold a broader corpus of films that induce affective discomfort, revel in visual excess and whose mode of address is predicated on sensory immediacy.

More recently, scholars have started to challenge the fundamental tenets of the cinéma $d u$ corps - namely, the idea that the body of the spectator is synergistically intertwined with the 'body' of the film — by calling into question the potentially tautological proximity between film theory and its objects. Affect, a term that is routinely deployed in earlier writing, often through a phenomenological or Deleuzian lens, has been the subject of Eugenie Brinkema's incisive study, The Forms of the Affects, which charts the waning of formal analysis and the concomitant ascendance of spectatorial sensation as a guiding force behind film scholarship (See Brinkema 2014, 26-36). For his part, Mauro Resmini has voiced skepticism about how the cinéma du corps promises 'a phenomenology of immediacy (in contrast with the mediating character typically associated with reason)' $(2015,163-4)$ and how such films purport to 'access this pure realm of sensation by divesting themselves of the framing of formal mediation between the spectator and the real' $(2015,164)$. The suggestion is that by emphasizing spectatorial affect as our heuristic a force commonly understood as immediate or pre-discursive — we fail to register both the generic framing of the film object and how it figures within a wider textual system. Given that the "“cinema of sensation" exceeds any existing code or taxonomy' as Resmini notes, genre is 
thus rendered 'an obsolete and ineffective epistemological category' $(2015,166)$. To broach questions of casting, performance, and consumption in relation to the cinéma du corps, would be to awkwardly reinstate the diegetic event qua construction. Such a move would appear as retrograde insofar as it would return us to the supposedly 'obsolescent' categories of conventional film analysis (genre, narrative, context) that the cinematic phenomenon originally sought to eschew.

Another recent study, Mattias Frey's Extreme Cinema (2016), offers a different, but not unrelated, critique of this tendency in art cinema. He argues that while the cinéma du corps is often subtended by discourses of transgression, exceptionalism and is buoyed by its countercultural cachet, it is nonetheless beholden to the same economic imperatives as commercial cinema. This fact, he argues, has been routinely disavowed in order to uphold its claims to aesthetic autonomy and philosophical seriousness. In their respective investigations into the framing, mediation and discursive construction of cinematic extremity both Resmini and Frey invoke Steve Neale’s seminal essay ‘Arts Cinema as Institution’ (1981), an important piece of criticism with the express aim of demystifying the exclusive label of 'art cinema' and questioning its propensity towards generic exceptionalism (Resmini 2015, 167; Frey 2016, 6-16).

Questions of casting and commerce (and, by extension, the subdiscipline of star studies) clearly fit uneasily in relation to the picture sketched above. The concept of the film star is paradigmatically understood as an aggregate of on-screen selves, 'an intertextual construction produced across a range of media and cultural practices' (Gledhill 1991, XIV), a 'repertoire of gestures, intonations, etc. that a star establishes over a number of films' (Dyer 1979, 142). Given that this is a phenomenon that signifies between discrete performances, exceeding the boundaries of any given film text, it implicitly threatens the closed textual circuit within which the cinéma $d u$ corps is understood to operate. A holistic approach to star studies, attentive to context and 
paratext, exists at a considerable distance from the cinéma du corps' promise of pure sensation because it threatens, as Bordun puts it, to 'break spectatorship from pre-discursive immanence' $(2017,195)$.

This incompatibility begs a fairly simple question. Does the fact that this methodological antagonism has been underdiscussed not simply suggest that there is little necessity to do so? While very few prominent actors demonstrate a willingness to tarry with the nexus of sex and violence for fear either of generic pigeonholing or reputational damage, Isabelle Huppert clearly figures as a notable exception. Her collaboration with filmmakers such as Catherine Breillat, Claire Denis, Michael Haneke and Christophe Honoré suggests a proximity to the genre of cinematic extremity but her work also highlights some of its limitations. Not only does her filmic presence complicate common accounts of the cinéma du corps, but her extensive archive of daring performances serves also to question the (increasingly untenable) 'newness' imputed to the 'new French extremity'.

This argument also runs in the opposite direction. Among the hallmarks of Huppert's performance are her much-lauded impassivity and emotional opacity. Huppert's subversion of common understandings of the film star as a vessel for spectatorial identification has led critics to dub her French cinema's 'anti-star' and associate her with affectlessness and de-dramatization (Boussageon 2014). Moreover, while scholars of stardom writing in the wake of Richard Dyer have typically foregrounded ephemera, contingency, lifestyle details and gossip as constitutive parts of the star's paratext, it is difficult to locate such instances of personal disclosure or willed loquacity in the discourses that surround Huppert's off-screen persona.

While I have suggested above that there is little to connect studies of stardom and extremity, perhaps their common concerns converge around the site of the body. On the one hand, Neale notes that 'the tradition of Art Cinema' (within which the tradition of the cinéma du 
corps is now comfortably nestled) 'has always been concerned with the inscription of representations of the body' (1981,31; emphasis added), while Gledhill, writing in a very different register, notes that '[s]tars reach their audiences primarily through their bodies' (1991, 214; emphasis added). Although proponents of the cinéma du corps have encouraged a theoretical shift from the realm of the profilmic towards the embodied site of reception, Huppert invites us to return to the former register given that her dramatic style ruptures the link between emotionally legible on-screen subjects and the empathic reaction of the spectator. Moreover, the status, stardom and cultural weight of Huppert brings a supplementary layer of mediation which, I argue, inflects our reading of her on-screen performances.

Before discussing three examples from Huppert's post-2000 filmography which complicate discourses of extreme cinema, I briefly want to revisit a previous reading of her image to tackle a pressing question prompted by the critiques surveyed above. Much early writing on the cinéma $d u$ corps has, by virtue of the putative philosophical import of its object, eschewed questions of cultural reception (Resmini's so-called 'ineffective' analytic categories), which are the mainstay of more traditional film scholarship. It is therefore telling to note that the most striking piece of scholarship to call into question these presuppositions - Tina Kendall's contribution to The New Extremisms - opens by centring on a picture of Isabelle Huppert. Commenting on the promotional poster of Christophe Honoré's Ma mère (2004), a Bataille adaptation which Nick Rees-Roberts $(2008,97)$ aptly situates within a 'much-lauded cultural package of transcendence through perverse sexuality', Kendall notes how in some versions of the poster the film's eponymous mother (Hélène, played by Huppert) is pictured with a cigarette, while in posters destined for French and British audiences this detail has been airbrushed out. The omitted detail speaks powerfully in Kendall's analysis, signaling 'the contradictory status of transgression in our era of global consumer capitalism' $(2011,43)$. It also suggests the primacy that film 
censorship takes over any narrative infraction of the symbolic Law (namely, Honoré's exploration of incest), which starts to reveal the hollowness of the film's political and philosophical discourse. The roles of the film star and cinematic paratexts are clearly instructive here. Throughout the rest of this chapter, I explore further how Huppert demands us to qualify these discourses. My aim is to trace the gestural economy of the imperilled body across Huppert's more recent body of films which unmoors the zeitgeist of the cinéma du corps from a fixed space and time, as well as from its conceptual certitudes.

\section{Exacting punishment: La Pianiste}

The film that cemented Isabelle Huppert's reputation for extremity, Michael Haneke's La Pianiste (2001), entertains a close but complicated relation to the cinéma du corps. While the film clearly engages with questions of embodiment and transgression, critics have noted how it is marked by a restraint and asceticism. For Catherine Wheatley, the film operates according to principles of minimalism, precision, and distanciation $(2011,182)$ while Brigitte Peucker writes that it exhibits 'the formal rigor of [its] modernist sources' $(2007,131)$.

Haneke's adaptation of Elfriede Jelinek's 1983 novel, Die Klavierspielerin, presents the story of Erika Kohut, an austere and psychosexually troubled woman in her late thirties who teaches piano at the Vienna Conservatoire and who lives in a fraught oedipal proximity to her mother (Annie Girardot). La Pianiste is underwritten by a dialectic of desire and restraint; while we might at first assume that Erika's desires find their expression and fulfilment in her musical virtuosity, an unsublimated remainder spills over into acts of perversity, jealousy, and sadomasochism which are relentlessly catalogued as the film unfolds. Between Erika's teaching duties at the Conservatoire and the nightly return to her overbearing mother there exists a narrow window of time in which she takes calculated detours throughout the city. The first excursion is 
to the video booth of a sex shop where Erika fumbles around for used tissues, sniffing the postmasturbatory detritus of the cubicle's previous occupants. Later, we witness Erika attending an outdoor cinema screening. She hovers by a car window in order to spy on a young couple who are engaged mid-coitus, and as she edges towards them in her distinctive Burberry mac (a garment which carries aptly contradictory connotations of demureness and exhibitionism) she starts to urinate uncontrollably. The beginning of the film thus dedicates itself to the indexing of Erika's drives. These paraphilic acts are — to adopt the psychoanalytic lexicon conveniently provided to us by virtue of the film's setting — indicative of polymorphous perversion. Although Erika works assiduously to maintain a hygienic distance between work life and her increasingly unmanageable sexual proclivities, the two become increasingly entangled when she reluctantly takes on the tutelage of Walter Klemmer (Benoît Magimel), a persistent young student who initiates the transgression of the pedagogical relation. We later learn that Erika will only engage with Walter sexually in accordance with a set of sadomasochistic strictures that she has dictated beforehand and which are communicated — or rather notated — by way of letter. Erika's epistolary mode of address signals a double transgression relating both to the film's content as well as its genre. The film's impropriety inheres not only in the panoply of punishments that constitute its violent contents itself, but it is also lodged in its mode of communication. In opposition to the contingency, and messiness of the cinéma du corps, its 'informe' (Beugnet 2007, 65), the character of Erika entertains the fantasy, which we will later learn to be a categorical error, that the vicissitudes of sex and violence can be marshalled and choreographed in a manner akin to a musical score or stage direction.

At the point of initial conception, Michael Haneke informed Huppert that he would only pursue the film project if she agreed to the role of Erika; a choice that would thus necessitate the linguistic transposition of Jelinek's German source text into French, all the while remaining in 
Vienna. This dual affiliation represents more than mere happenstance, however, as the casting of Huppert allows for two different intellectual and artistic genealogies to come to the fore. John Champagne (2002) has suggested that the Austro-French origins of La Pianiste invoke two traditions of psychoanalytic discourse, those stemming back to Freud and to Lacan (although we might also evoke two avatars of psychosexual perversion here: Sacher Masoch and Sade). But while it might be tempting to read Huppert's presence here as metonymically bound up with notions of 'Frenchness', her running commentary in the film demonstrates a capacious grasp of the histories of artistic transgression in the film's site-specific context. Early on in the film we witness Erika enclosed in her bathroom, taking a razor blade to her sex before ritualistically cleaning her bath with water and returning the sharpened implement to a bag. Tempting though it may be to frame the scene of auto-mutilation in the contemporary frame of extremity, Huppert's comments gestures further back to a 'politico-aesthetic movement' in the Austrian avant-garde of the 1970s, which I take here to be an oblique reference to Viennese actionism. Her astute rejoinder offers a more apposite relation between the film's visual tactics and the bourgeois mores that it seeks to repudiate. While extreme cinema aims to dissimulate national and contextual consideration, 'attempting to shift from representation to pure presentation' (Resmini 2015, 171), Haneke and Huppert's co-constituted project is a more ambitious project that plays with cultural registers — the pornographic, vernacular, modernist and classical — in order to reconfigure relations between pre-discursive sensation and cultural signification.

Moreover, the film's recalibration of affect is also tied to Huppert's performance style; Haneke's distinctive way of framing bodies, combined with the precision of Huppert's postural and gestural repertoire, helps to distinguish La Pianiste from the more gratuitous films that we might otherwise count among its contemporaries. Extreme close-ups are eschewed in favour of mid-length shots (plans américains) which register the movement of Erika's body through time 
and space. As we follow her seamless passage from a chamber recital through to a sex shop (set to the sound of Schubert's Piano Trio No. 2 in E flat major, bleeding from a diegetic to extradiegetic soundscape) Haneke's choreography limns the border between spaces of respectability and impropriety, the culturally sanctioned and socially maligned. The precise geometry of the film, with its recurring patterns of black and white grids (flooring, piano keys, elevator grills) brings the tension between Erika's interior drives, physical body, and her environs into stark relief. Such a tension is emblematized in the film's promotional poster, which depicts Erika and Walter's passionate embrace; the forms of their bodies contrast with the sterile rectilinearity of the bathroom surroundings, suggesting the obduracy of bodies whose desires and materiality cannot be properly contained.

Rather than succumbing to corporeal hyperbole, La Pianiste focuses painstakingly on small gestures. The wiping of Erika's hands on her shoulders before she enters the sex shop, the frequent rearrangement of clothing, even mid-length shots of her back, achieve a remarkable force in spite of their contentlessness. What we might otherwise read as contingent or asignifying details seem to index Erika's various affective states: ennui, discomfort, her willed composure in the face of threat. For Alison Taylor, such 'microgestures' demonstrate 'Huppert's mastery, intuitively recruiting the vocabulary of the agitated body and preoccupied mind: the latter's tension necessarily expelled through the former' $(2018,222)$. This cathexis of, and overinvestment in, the detail (a form of metonymic reading which, we must remember, forms a touchstone in star studies from Barthes through to Dyer) thus helps us to grasp at the film's opaque sexual politics. Moreover, Huppert's calculated minimalism corresponds with Haneke's own ambition in this film to extract the greatest affect by disclosing the least; a logic of inverse proportionality that exists in contradistinction to what James Quandt has diagnosed as the cinéma du corps' visual politics of excess and gratuity (2011, 18-19). 
Yet, it is the final scene of La Pianiste that offers its most pointed reversal of how affect and embodiment has been understood to interact in much existing film scholarship. Following a grueling scene in which Erika is subject to battery and rape, we revisit the space of the Conservatoire to witness her final recital. Continuing Haneke's strategy of disclosing acts of violence in advance — and thereby evacuating them of their narrative contingency or 'shock value' - we watch Erika take a knife from her kitchen and place it in her bag. She lingers in the entrance lobby of the Konzerthaus before passing Walter Klemmer with two younger women. She reaches into her bag and plunges the knife into her chest, emitting a small grimace. The cut to the body is followed by the film's final cut: a pool of blood starts to swell into a deliquescent pattern on her chiffon blouse before the camera jumps to a frontal shot of the building's imposing edifice. Disrupting the symmetry of the architectural shot, we watch Erika escape to the right of the frame. Although there is a near analogy between both 'cuts', suggesting a concordance between the finitude of the on-screen body and the metaphoric 'body' of the film, this ought not to be confused with the way in which affect, embodiment and filmic violence has heretofore been understood in much recent film theory. In the denouement of La Pianiste, the rectilinearity of the architecture (with its attendant connotations of moral rectitude) and the affectlessness of Huppert offers little to the spectator in terms of effective reprieve or affective catharsis. The relation between on- and off-screen bodies is severed decisively. ${ }^{2}$

Lisa Courthald $(2011,180)$ has written of how Haneke works to problematize clear-cut delineations between violence and non-violence, and I have sought to argue that Huppert's style of performance further cultivates this ambiguity. On the occasions that the film offers us respite from ostensibly graphic violence, it lingers with scenes of rehearsal — or to adopt the more fittingly polyvalent French word, répetitions. The notion of repetition in La Pianiste speaks both to an understanding of traumatic repetition in the Freudian schema to which I alluded earlier, as 
well as naming the processual character of Erika's transgression. Interweaving the twin demands of Erika's musical and sexual training, which run in parallel throughout the narrative, Joudet writes that Huppert's body 'must fold to the exigencies of her art' $(2018,134)$. While La Pianiste deftly explores these multifaceted themes of mastery — whether artistic, pedagogic, erotic, or sadomasochistic — through a visual appeal to the pliability and dexterity of Huppert's body, these dynamics have been taken in a very different direction in her later work.

In a more recent performance as the protagonist of Catherine Breillat's Abus de faiblesse/Abuse of Weakness (2013), Huppert once again portrays 'a woman who is out of sync with her body, but has to train it' (Joudet 2018, 190). The thematic territory of Breillat's film is markedly different though, given that Huppert offers a harrowing portrayal of a stroke-addled body. While there exist clear risks in extending the remit of the cinéma du corps, charting a continuum between the new extremity into a recent foregrounding of the disabled body (not least because of the pitfalls of conflating subjects keyed in very different ethical registers), Kath Dooley notes how this film contains a thematic appeal to the contiguous relations between sexuality and power while pushing the limits of the body $(2018,3-4)$ and Troy Bordun similarly notes a broader tendency in contemporary art cinema to 'turn[...] to another type of body in the throes of ecstatic states, namely, the ill or suffering body' $(2017,226)$. In Breillat's film, the body of Huppert undergoes further processes of training and remastery, yet in this performance this focus on gesture and repetition serves a reparative function.

\section{From repetition to reparation: Abus de faiblesse}

Abus de faiblesse provides a loosely autobiographical account of the French director Catherine Breillat's experience of a stroke which rendered her partially paralyzed and susceptible to the exploitation of the high-profile con man, Christophe Rocancourt. The story was originally 
recounted in Breillat's 2009 memoir, but in the film her characters assume pseudonyms (Huppert plays protagonist Maud Shainberg, and the conman Vilko Piran is played by Kool Shen). Following a lengthy convalescence and ongoing physiotherapy treatment, Maud resumes her next film project entitled Bad Love, a feature about a film star's infatuation with a 'common man', which escalates into a violent relationship with fatal consequences. While watching late night television in a state of drowsiness and fatigue, Maud is captivated by dangerous airs of the man on-screen, Vilko. She rings her producer and demands to meet the rugged neophyte. Vilko fits the bill for her project and he swiftly agrees to the role on the understanding that he is not forced to undergo the indignity of a screen test. The film documents their intimate yet fraught entanglement before the start of the film shoot. While the steadfast, resolute Maud attempts to assert her independence and agency, she is taken advantage of financially and emotionally, which leads her to launch a prosecution against Vilko on the grounds of the titular 'abuse of weakness'.

The film figures a mise en abyme at three levels, comprising Breillat's own experience, Huppert's portrayal in the film, as well as the mention of the film project Bad Love, which, despite only a cursory synopsis, fits squarely into the 'extreme' mode of filmmaking for which the earlier Breillat is better known. Though the cinema of Catherine Breillat has been afforded a central position within the French extremity, a closer look starts to reveal fault-lines in respect to the overarching discussion that I sketched out above. While frequently adopting the extreme close-up, a cinematographic trope which we might understand as opening up a plane of 'prediscursive immanence', Troy Bordun notes also Breillat's reflexive breaking of the fourth wall $(2017,195)$. Her filmography constitutes a complex intertextual whole, with prior projects feeding directly into future ones (the on-set dynamics of $\grave{A}$ ma soeur!/Fat Girl (2001) spurred the genesis of her later film Sex is Comedy (2002) for example), as well as interrogating the role and 
signification of her actors outside of the diegetically contained scenes that she constructs. Quite contrary to the dominant account of extreme cinema set out earlier, then, the extratextual connotations of performers are not dissimulated by Breillat. Rather, as Emilija Talijan (2018, 312) has recently argued, they are routinely enfolded into the fabric of her narratives; cinematic bodies attain their own reflexive currency.

The strategy attains a particular significance with regard to Isabelle Huppert, whom Breillat had known intimately for the previous four decades even though their long-standing relationship was punctuated by a string of missed encounters at the level of filmography (Joudet 2018, 189). In a discussion of the film's casting, Breillat called Huppert 'the most intellectual French actress', noting the contradictions of her star persona: 'simultaneously hard and child-like' (Entrée libre 2015). Continuing this somewhat discomfiting triage of minds and bodies, Breillat explained that in order to accentuate Huppert's star presence, she had to be cast against a 'cinematographic virgin' (Kool Shen), a body that is not in — or of — the cinema. This film's sexual politics therefore draw reflexively on the corporeal codes of its actors, and the material and symbolic forces that accrete around their bodies.

The film opens with a sparse soundscape: the steady meter of a heartbeat, a drone and the foreboding whisper of tremolo strings. A medium-length shot tracks an upward motion through the folds of white bedsheets to reveal a frail Maud lying in bed before her eyes gradually open. Her left hand starts to touch her right arm which appears weak, contorted, unresponsive. An increasingly panicked look in her eye, coupled with her unsteady gestures of auto-affection, suggests that she has undergone a stroke. She loses balance as she attempts to get up from the bed and her slight, frail body is framed in contradistinction to the oil painting of a reclining nude that hangs opposite her. The following shot captures her lying prostrate on the floor, and the subtle desaturation of this image suggests a lack of vitality. 
Subsequent scenes follow the routines of Maud painstakingly. The camera tracks her physical and speech-based therapy often in voyeuristic close-up, while the period of convalescence in the hospital ward is relayed in a flat, observational mode with minimal cinematographic intervention. Breillat's use of the long take, a now-ubiquitous staple of art cinema intended to attune spectators to the hefty lag of uneventful time, evokes a very different calibration of embodiment.

As with La Pianiste, Huppert plays a character who directs other bodies, but is also susceptible to weakness herself. Haneke and Breillat both marshal Huppert's performance style in order to trace the contiguous relation between sex and pain, agency and embodiment. In a visual echo to this comparison, there exist striking similarities in the posters of both films. The gendered dynamics of both images are by no means clear-cut; while Huppert is shown in both images to be holding onto her male counterpart, they are nonetheless figured as a 'support' in the physical and the narrative sense. Given that the cinéma du corps has typically explored the interrelated nexus of interpersonal violence, embodiment, and sexual politics in a generically limited sense, Abus de faiblesse suggests alternative ways of figuring psychic and physical vulnerability. Huppert's extensive filmography and the myriad intertextual resonances between her films seem to signal a more general shift beyond the limits of the normative body as well as moving her own performances, as well as Catherine Breillat's oeuvre, into fresh thematic terrain.

\section{Elle, the imperiled body and the graphic image}

In closing, I want to briefly turn to Huppert's performance in Paul Verhoeven's 2016 thriller Elle, which in many ways crystalizes the ideas that I have discussed above. While I risk belaboring these connections, we can again note that Huppert explores the corporeal and psychic dimensions of sexual violence while occupying ambivalent positions of maturity, seniority, and 
vulnerability in relation to her younger male counterparts. (Indeed, for this performance, she was recipient of the Alliance of Women Film Journalists' 2016 prize for 'Actress Defying Age and Ageism’.) Adapted from Philippe Djian's novel Oh!, Elle follows the life of an executive, Michelle, who works as the creative director of a Parisian computer game company which caters to its (overwhelmingly young male) audience by specializing with graphic, fantastical fare. The film opens with particular brutality as we bear witness to the rape of Michelle by a masked assailant in her home. The narrative then proceeds to explore the repercussions of the unreported attack, while also exploring the professional, social, and familial milieus of bourgeois Paris with an improbable, and to many critics unpalatable, combination of violence and suspense, humor and satire. The film offers a meditation on the visual economy of violence in the world of videogaming — a fantasy world cut to the measure of male desire — yet these dynamics appear unsettlingly consubstantial with the central plot. While perhaps marking the furthest remove from the aforementioned cinema of extremity in terms of genre and periodization, Verhoeven's film contains a number of elements which recall Huppert's earlier work. Like both aforementioned films, Elle limns an ethically tricky terrain between sex and violence, and its narrative is conversant in (though not fully commensurate with) the language of psychoanalysis. And once more, her body — falling, prone, or supine — resurfaces throughout as a key visual motif, a gestural refrain. Much of the commentary sparked by the film has centered on the ethics of representing sexual violence. Critics have focused particularly on the illegibility of Michelle's paroxysms, seemingly oscillating between the throes of pain and pleasure, as she choreographs a violent encounter with her attacker as the film reaches its denouement. However, the frame that I want to linger on in closing focusses not on the materiality of Huppert's body, but rather the abstraction of her face. 
The narrative intrigue of the thriller revolves around the undisclosed identity of the masked attacker. Though we later learn this to be Michelle's neighbor, Patrick (played by Laurent Lafitte), we first suspect that the rapist works in her office. In the scene that cements this ruse, we witness the computer screens in Michelle's office being momentarily seized and collectively overridden by a graphic image. (Graphic in both senses: it is explicit and computer generated.) Michelle's face is superposed over that of a female video game character who is being penetrated violently by an ogre. INSERT IMAGE TWO HERE. The wireframe mesh of this digital rendering further underscores the claustrophobic dimension of the image. While the sequence serves a clear plot function, either as threat or premonition, the potency of the image arises from the fact that it signifies in excess of the immediate narrative level. By dislocating, and thus decontextualizing, the photograph of Michelle from the digital environs in which the image circulates, Verhoeven also effects a rupture in the film's diegetic fabric. What we are plainly confronted with here is also an image of Huppert's face, an icon which as so many critics have argued, has attained meta-cinematic status and cultural currency. While Verhoeven's film does seek to explore the limits of the body in material, palpable, and 'brutally intimate' terms (Palmer 2011, 57), the casting of Huppert once again effects a move beyond the immediacy of the profilmic plane. The graphic sequence points reflexively to the remediation of photographic images. By turning the face of the star into an avatar, it gestures implicitly to the broader archive of Huppert's performances in which her face has also attained, to use the term Brigitte Peucker uses in her analysis of La Pianiste, 'the impassive expression of a mask' $(2007,152)$.

Returning to the contention at the beginning of this chapter, Huppert's predisposition for roles that tarry with questions of sex and violence often attains a troublingly intertextual quality. Or, as Mick LaSalle notes, '[s]he presents us with perversity and dares us to make a personal' [which is to say: extra-diegetic] 'connection' $(2012,80)$. Indeed, the subtitle of LaSalle's study, 
'What Hollywood Can Learn from Contemporary French Actresses', ought to be taken as particularly instructive here. To extend this formulation, I wish to suggest that contemporary French actresses tell us much about the omissions of film theory, too. Put simply, the 'daring' of Huppert, by which I mean her unflinching attitude towards performance and casting, ought to prompt further discussion about exactly which questions have (and more importantly, haven't) found themselves discussed within the remit of star studies.

Taking Isabelle Huppert as my case study, I have sought to signal a friction between diverging ways of theorizing performance, embodiment and extremity in contemporary cinema. While Tanya Horeck and Tina Kendall have traced the origins of the 'new extremism' back to France $(2011,2-5)$, and the 'intellectual', 'cerebral' and 'transgressive' Huppert is frequently held up as an exemplar of what has been euphemistically described as 'French' discourses on sexuality, a closer interrogation of her performances in post-2000s art cinema suggests a certain resistance to national and generic pigeonholes. The overdetermination of her star image, coupled with her subversion of the visual codes of the cinéma du corps, frequently moves us out of the conceptual myopia that scholars such as Resmini and Frey have so brilliantly diagnosed. Huppert's extensive archive also invites us to trace affinities through her body of work and back to her earlier performances, in ways that trouble film studies' penchant for premature periodization. Joudet's $(2018,15-20)$ impassioned account of her relation to Breillat — a reading which frequently succumbs to creative anachronism by speculating just as much about those many paths not taken - offers just one illustration of this tendency. Critical accounts of Elle, and particularly those which invoke La Pianiste as a cinematic touchstone, raise further questions still about the ethical dimension of intertextual signification.

Yet, while it might ultimately be tempting to conclude that the lesson that Huppert offers to film studies is to jettison overarching theories and neat periodizations with the very air of 
insouciance that she has made her hallmark, we ought not to lose sight of the ways in which her own - often vocal, often opaque — rejection of the 'theoretical' tenor of film criticism is intellectually motivated itself. Or, as she put it in her characteristically slippery idiom for a February 2019 interview in The Independent: 'I don't play a character. I just play an encounter between me and certain states of mind. Is that clear?'

6922 words

\section{Notes}

* My gratitude to Emma Wilson, for stimulating discussions in the early stages of research and Kyle Stevens, who made valuable secondary material available to me.

1. Unless otherwise indicated, all translations from French are my own.

2. On the relation between cinematic form and embodied injury in La Pianiste, see Fleishman 2019, 186-188.

3. Djian's novel is set in the industry of film production, rather than video game entertainment. This transposition of media is interesting given that it reanimates continued debates surrounding the supposedly mimetic logic of video game violence.

Jules O'Dwyer is a doctoral student in Film Studies and French at the University of Cambridge and Director of Studies in Modern and Medieval Languages at Corpus Christi College. He has published widely on topics related to French and Francophone visual culture, film theory and queer theory in journals including Screen, Discourse and Studies in French Cinema. 


\section{References}

Álvarez López, Cristina and Adrian Martin. 2017. "Isabelle Huppert: The Absent One.” Third Rail (10): 21 - 26.

Beugnet, Martine. 2007. Cinema and Sensation: French Film and the Art of Transgression. Edinburgh: Edinburgh University Press.

Birchall, Bridget. 2005. "From nude to metteuse-en-scène: Isabelle Huppert, image and desire in La Dentellière (Goretta, 1977) and La Pianiste (Haneke, 2001).” Studies in French Cinema 5 (1): $5-15$.

Bordun, Troy. 2017. Genre Trouble and Extreme Cinema: Film Theory at the Fringes of Contemporary Art Cinema. Basingstoke: Palgrave McMillan.

Boussageon, Alexandre. 2014. "Isabelle Huppert, actrice-caméléon et anti-star". Nouvel Observateur. 23 October 2014. https://www.nouvelobs.com/culture/20090102.OBS7987 /isabelle-huppert-actrice-cameleon-et-anti-star.html.

Brinkema, Eugenie. 2014. The Forms of the Affects. Durham, NC: Duke University Press. Champagne, John. 2002. “Undoing Oedipus: Feminism and Michael Haneke's The Piano Teacher." Bright Lights. brightlightsfilm.com/wp-content/cache/all/undoing-oedipus-feminismmichael-hanekes-piano-teacher.

Coulthard, Lisa. 2011. "Interrogating the Obscene: Extremism and Michael Haneke." in The New Extremism in Cinema: From France to Europe, edited by Tanya Horeck and Tina Kendall, 180-191. Edinburgh: Edinburgh University Press. 
Dooley, Kath. 2018. “C'était moi mais ce n'était pas moi': portrayal of the disabled body in Catherine Breillat's Abus de faiblesse." Studies in French Cinema,19 (2): 1-15.

Dyer, Richard. 1979. Stars. London: BFI.

Entrée libre, 2015. “Catherine Breillat, Anatomie d'une réalisatrice,”14 April 2014. Video, 4:14. www.youtube.com/watch?v=v6TNZfrIBgE.

Film Comment, 2016. "Representing History + Isabelle Huppert Interview,” 8 March, 2016.

Audio, 65:39. http://www.filmcomment.com/blog/representing-history-isabelle-huppertinterview.

Frey, Mattias. 2016. Extreme Cinema: The Transgressive Rhetoric of Today's Art Film Culture. New Brunswick: Rutgers University Press.

Fleishman, Ian. 2018. An Aesthetics of Injury: The Narrative Wound from Baudelaire to Tarantino. Evanston, IL: Northwestern University Press.

Gledhill, Christine. 1991. Stardom: Industry of Desire. London; New York: Routledge. Joudet, Murielle. 2018. Isabelle Huppert: Vivre ne nous regarde pas. Paris: Capricci. Kendall, Tina. 2011. "Reframing Bataille: On Tacky Spectatorship in the New European Extremism." in The New Extremism in Cinema: From France to Europe, edited by Tanya Horek and Tina Kendall, 43-54. Edinburgh: Edinburgh University Press.

LaSalle, Mick. 2012. The Beauty of the Real: What Hollywood Can Learn From Contemporary French Actresses. Stanford: Stanford University Press.

Neale, Steve. 1981. “Art Cinema as Institution.” Screen 22 (1): 11-40. 
Palmer, Tim. 2011. Brutal Intimacy: Analyzing Contemporary French Cinema. Middletown, CT: Wesleyan University Press.

Palmer, Tim. 2007. "Under Your Skin: Marina de Van and the contemporary French cinéma du corps." Studies in French Cinema 6 (3): 171-181.

Peucker, Brigitte. 2007. The Material Image: Art and the Real in Film. Stanford: Stanford University Press.

Quandt, James. 2011 [2004]. "Flesh and Blood: Sex and Violence in Recent French Cinema." in The New Extremism in Cinema: From France to Europe, edited by Tanya Horeck and Tina Kendall, 18-28. Edinburgh: Edinburgh University Press.

Rees-Roberts, Nick. 2008. French Queer Cinema. Edinburgh: Edinburgh University Press. Resmini, Mauro. 2015. "Reframing the New French Extremity: Cinema, Theory, Mediation." Camera Obscura 30 (3): 161-187.

Royer, Michelle. 2015. "Mystère, intellectualisme, authenticité et impertinence: Isabelle Huppert en jeu." Australian Journal of French Studies 52 (2): 149-161.

Sight and Sound. 2017. “Certain Women, Elle, Moonlight and Nocturama - four 2016 highlights, debated," 5 January 2017. Audio, 33:53. https://www.bfi.org.uk/news-opinion/sight-soundmagazine/podcast-certain-women-elle-moonlight-nocturama-2016-london-film-festival. Talijan, Emilija. 2018. "Les petits bruits: little noises and lower volumes in Catherine Breillat's Romance (1999) and Anatomie de l'enfer (2004)." Studies in French Cinema 18 (4): 310-325. Taylor, Alison. 2018. "Isabelle Huppert in The Piano Teacher." in Close-Up: Great Cinematic Performances Volume 2: International, edited by Murray Pomerance and Kyle Stevens, 217227. Edinburgh: Edinburgh University Press. 
Wheatley, Catherine. 2011. "Unseen/Obscene: The (Non-)Framing of the Sexual Act in Michael Haneke's La Pianiste" in New Austrian Film, edited by Robert Von Dassanowsky and Oliver C. Speck, 177-188. Oxford; New York: Berghahn. 